\title{
SITUS SEJARAH PEREKAT KERUKUNAN DAN MAKNANYA DALAM KEHIDUPAN BERBANGSA DAN BERNEGARA
}

\author{
Ida Bagus Brata ${ }^{1}$, Rulianto ${ }^{2}$, Ida Bagus Nyoman Wartha ${ }^{3}$, I Putu Adi Saputra ${ }^{\mathbf{4}}$ \\ Program Studi Pendidikan Sejarah, FKIP, Universitas Mahasaraswati Denpasar ${ }^{1,2,3,4}$ \\ Email: ibbrata@unmas.ac.id
}

\begin{abstract}
ABSTRAK
Kajian ini mencoba menelaah peranan situs sejarah sebagai perekat kerukunan bangsa di tengah kemasakinian yang begitu problematis. Sejarah adalah hasil rekonstruksi cipta, rasa, karsa, dan karya manusia masa lalu, namun bagaimana memosisikan situs sejarah agar tetap berperan bagi masa depan suatu bangsa. Situs sejarah mengandung berbagai emosi di dalamnya yang harus dinarasikan. Sejarah membangkitkan keinsyafan akan dimensi ruang dan waktu yang sangat esensial dalam eksistensi manusia. Penelitian ini dirancang secara kualitatif dengan pendekatan alamiah, ditunjang studi pustaka, dengan menempatkan peneliti sebagai instrumen kunci. Pengambilan sampel secara purposive, pengumpulan data dilakukan dengan teknik triangulasi, analisis data bersifat kualitatif interpretatif. Hasil penelitian menunjukkan bahwa pemanfaatkan situs sejarah sebagai sumber belajar dan media penghubung adalah sesuatu yang sangat strategis di tengah dinamika masyarakat yang mengarah ke arah bebas sekat. Situs sejarah dapat berperan sebagai media yang menghubungkan masa kini dengan masa lalu. Situs sejarah dapat dijadikan sebagai simbol perekat kerukunan bangsa. Sebagai simbol kerukunan, situs sejarah mengandung nilai dan makna simbolik, informatif, estetik, dan ekonomi dalam upaya membangun masa depan bangsa yang lebih baik.
\end{abstract}

Kata kunci: Situs sejarah, perekat, kerukunan, jati diri.

\section{ABSTRACT}

This study tries to examine the role of historical sites as the glue of national harmony amidst problematic security. History is the result of reconstruction of past human creations, feelings, initiatives, and works, but how to position historical sites so that they continue to play a role in the future of a nation. Historical sites contain various emotions in them that must be narrated. History awakens the realization of the dimensions of space and time which are essential in human existence. This research was designed qualitatively with a natural approach, supported by literature studies, by placing the researcher as the key instrument. Sampling was purposive, data collection was carried out by triangulation techniques, data analysis was interpretive qualitative. The results of the research show that the use of historical sites as learning resources and connecting media is something very strategic in the midst of the dynamics of society that leads to barrier-free. Historical sites can act as a medium that connects the present with the past. Historical sites can be used as symbols of the glue of national harmony. As a symbol of harmony, historical sites contain symbolic, informative, aesthetic, and economic values and meanings in an effort to build a better future for the nation.

Keywords: Historical site, adhesive, harmony, identity.

\section{PENDAHULUAN}

Sejauh ini pendidikan sejarah yang diajarkan di sekolah dipersepsikan sebagai pendidikan untuk kehidupan masa lampau, tidak terkait dengan kehidupan masa kini, apalagi di masa yang akan datang. Pengajaran sejarah hanya berkisar di sekitar kemampuan menghafal fakta dan cerita sejarah, kurang diberikan ruang untuk menjawab tantangan kehidupan masa kini ataupun masa yang akan datang, baik bagi siswa, masyarakat atau bangsanya. Materi sejarah yang diajarkan di sekolah masih berkutat pada pendekatan chonicle dan cenderung menuntut anak agar mampu menghafal suatu peristiwa (Abdullah, 2017). 
Dengan memosisikan pendidikan sejarah seperti itu, maka peserta didik lebih memandang bahwa pendidikan sejarah hanya menjadi mata pelajaran pelengkap atau hanya menjadi sekedar bukti bahwa bangsa ini tidak meninggalkan atau melupakan sejarahnya (jasmerah). Namun apapun alasannya, yang jelas di masyarakat telah terbangun sebuah stigma bahwa mata pelajaran sejarah hanya sebagai beban belajar peserta didik.

Pembelajaran sejarah yang demikian, maka cenderung sejarah dipahami sebagai masa lampau dan masa lampau adalah masa lalu yang tidak lagi berguna untuk membangun kehidupan berbangsa dan individu warga negara yang produktif (Hasan, 2017). Materi sejarah dalam bentuk cerita sejarah tidak dipandang sebagai sesuatu yang inspiratif, sehingga tidak mungkin dapat digunakan untuk membangun kehidupan masa kini maupun masa depan. Cara pandang seperti ini tentu sangat berbahaya, karena menghilangkan dimensi diakronis-kronologis sebuah peristiwa sejarah. Artinya sejarah dipahami secara parsial terputus, tanpa dirangkai dengan peristiwa sebelumnya, padahal sejarah merupakan rangkaian peristiwa masa lalu, masa kini, dan sebagai pembanding masa yang akan datang.

Merupakan suatu kenyataan yang tidak terbantahkan bahwa mata pelajaran sejarah sejak SD sampai SLTA/sederajat selalu sama, yaitu bercerita tentang kejayaan masa lalu dan kemerdekaan secara monoton tanpa ada kekuatan untuk membangun kemampuan berpikir peserta didik secara kritis, kreatif, dan inovatif. Peserta didik jarang, atau bahkan sangat kurang diberikan ruang dan kesempatan untuk mengembangkan daya kreasi serta imajinasinya. Akibatnya, pembelajaran sejarah terasa kering, kurang menarik, monoton, dan cenderung membosankan. Padahal pendidikan sejarah merupakan salah satu penguat pendidikan karakter peserta didik (Brata, 2019).

Pelajaran sejarah semestinya tidak menjadi sekedar lambang pemujaan masa lalu dengan membuat peserta didik hanya terpesona oleh gemerlap masa lalu yang digambarkan dalam materi sejarah. Tidak menjadikan peserta didik hanya terpesona terhadap situs sejarah sebagai warisan masa lalu tanpa makna. Penyajian materi seperti ini dapat dipastikan kurang bahkan tidak pernah berpikir untuk merencanakan bagaimana masa depan mereka (siswa) sendiri. Kalau seperti ini yang terjadi bagaimana peserta didik mampu menjawab permasalahan yang dihadapi dalam hidupnya, padahal mereka sadar bahwa setiap jaman memberi peluang dan tantangan yang berbeda.

Berdasarkan uraian di atas dan bila dikaitkan dengan arah dan tujuan, pendidikan sejarah di Indonesia tidak dapat dipisahkan dengan komitmen terhadap pembangunan bangsa. Pendidikan sejarah mempunyai tujuan untuk menanamkan dan mengembangkan kesadaran sejarah dalam diri peserta didik. Pendidikan sejarah dalam kaitan ini tentu lebih menekankan pada aspek pembelajaran, guna terbentuknya peserta didik yang memiliki kesadaran sejarah, yaitu menjadikan pengalaman historis sebagai referensi dalam menyikapi kehidupan masa kini (Wija, 2002; Yusuf, 2011). Pendidikan sejarah bertujuan untuk menyadarkan siswa akan adanya proses perubahan dan dinamika masyarakat dalam dimensi ruang dan waktu, di samping untuk membangun perspektif serta kesadaran sejarah dalam menemukan, memahami, dan menjelaskan jati diri bangsa di masa lalu, masa kini, dan masa depan di tengah kemasakinian yang begitu problematis. 
Semangat seperti ini sepertinya sejalan dengan tuntutan "manusia baru Indonesia" yang memuat tiga ciri utama seperti yang disampaikan oleh seorang futurolog Alvin Toffler (1991), yaitu: manusia berdasar Ipteks, kreatif, dan memiliki solidaritas etis yang tinggi, yang merupakan tuntutan manusia modern, yaitu kecepatan dan ketepatan antisipasi serta adaptasi terhadap problema yang setiap saat muncul dengan cepat.

Berangkat dari cara berpikir seperti di atas, maka situs sejarah sebagai tinggalan masa lalu bukan hanya untuk dibanggakan atau dikagumi, dilihat, dan dinikmati. Situs sejarah ini wajib digali, dikaji, dan direkonstruksi untuk mendapatkan gambaran tentang masa lalu yang dapat dijadikan sebagai pegangan masa kini untuk perbandingan guna menapaki masa yang akan datang. Apakah situs sejarah itu dapat dijadikan sebagai salah satu rujukan untuk merekatkan kerukunan bangsa. Ataukah situs sejarah tersebut masih memiliki nilai dan makna lain yang sangat berguna bagi bangsa ini. Atas dasar itulah situs sejarah sebagai hasil kejayaan masa lalu patut digali untuk direkonstruksi dan diinformasikan, serta dipelihara dalam arti dilestarikan untuk membangun peradaban dan kesejahteraan masyarakat, bangsa, dan negara utamanya bagi generasi penerus bangsa di masa depan.

\section{METODE PENELITIAN}

Rancang kajian ini adalah bersifat deskriptif dengan metode kualitatif interpretatif. Metode ini digunakan karena pada dasarnya pengumpulan data lapanganlah yang lebih dominan ditambah dengan penafsiran untuk mendapatkan maknanya. Interpretatif berarti menjelaskan segala sesuatu yang sesungguhnya di balik data yang ada (Black \& Champion, 2001).
Hasil penelitian ini berusaha menjelaskan suatu kondisi nyata yang ada di lapangan.

Dalam penelitian kualitatif, peneliti merupakan alat pengumpul data utama, oleh karena itu pada saat pengumpulan data di lapangan, peneliti berusaha untuk dapat berperan serta dalam berbagai bentuk kegiatan masyarakat (participantobservation) atau pengamatan terlibat, dibantu dengan teknik triangulasi. Agar wawancara dapat terarah dan efektif digunakan seperangkat instrumen dalam bentuk pedoman wawancara. Teknik wawancara yang diterapkan dalam kajian ini yaitu wawancara bebas terpimpin, artinya dalam melakukan wawancara disiapkan daftar pertanyaan secara garis besar yang dalam praktiknya dikembangkan di lapangan sesuai dengan data yang dibutuhkan. Oleh karena itu perlu ditentukan sejumlah informan yang mencakup berbagai person dan posisi, seperti: BP3 Bedulu Gianyar, pegawai Museum, Kepala Desa, tokoh agama, tokoh masyarakat yang terseleksi secara purposif.

Jenis data yang dipergunakan dalam kajian ini adalah data kualitatif, dalam wujud keterangan-keterangan secara deskriptif mengenai situs sejarah, seperti: lokasi situs, asal-usul situs, dan masa situs itu dibangun. Sementara sumber data dalam kajian ini dibedakan antara sumber data primer dan sumber data sekunder. Data primer diperoleh dengan melakukan pengamatan secara langsung ke situs-situs sejarah yang merupakan objek kajian. Observasi terhadap situs ini dilakukan untuk memperoleh wujud, kondisi, kepercayaan masyarakat, dan pemanfaatan situs sejarah. Data sekunder diperoleh melalui kajian pustaka, kajian arsip, jurnal, hasil seminar, lokakarya, dan sumber media koran serta internet (media sosial). Analisis data bersifat kualitatif interpretatif yang 
dilakukan secara bersamaan, yakni: reduksi data, penyajian data, dan penarikan kesimpulan atau verifikasi (Miles et al., 2014).

\section{HASIL DAN PEMBAHASAN \\ Situs Sejarah, Perekat Kerukunan, dan Maknanya Bagi Bangsa \\ Situs Sejarah Perekat Kerukunan dan Bermakna Simbolik}

Situs sejarah yang merupakan warisan masa lalu tersebar hampir di seluruh nusantara, mulai dari jaman praaksara, pengaruh Hindu dan Budha, masuknya budaya dan agama Islam, sampai kehadiran pengaruh Barat melalui aktivitas penjajahan. Situs sejarah banyak jenis, ragam, dan bentuknya. Situs sejarah tinggalan jaman praaksara misalnya punden berundak-undak, dolmen, altar, lukisan dalam goa dan sebagainya. Situs tinggalan jaman pengaruh kebudayaan Hindu dan Budha, misalnya kompleks percandian, istana kerajaan, permandian raja. Situs sejarah tinggalan jaman masuknya pengaruh budaya dan agama Islam seperti Masjid, makam para ulama atau para wali. Sementara situs sejarah tinggalan jaman pengaruh Barat, seperti benteng, monumen, kapal bawah laut dsb. Situs sejarah warisan masa lalu di dalamnya mengandung berbagai emosi yang begitu kaya berbagai narasi.

Situs sejarah dikatakan bermakna simbolik, karena situs sebagai warisan masa lalu merupakan fakta sejarah yang dapat menghubungkan masyarakat dengan masa lalunya. Melalui situs sejarah masyarakat masa kini dapat menghubungkan dirinya dengan masa lalunya. Situs sejarah menjadi perantara untuk menghubungkan antara masa lalu dengan masa kini umat manusia. Dalam kaitan ini, situs sejarah dapat bermakna simbolik, yaitu dapat menghubungkan masyarakat dengan masa lalunya. Artinya, situs sejarah dapat dijadikan sebagai media yang dapat menjembatani eksistensi manusia masa lalu dengan masa kininya.

Situs sejarah tinggalan masa lalu yang diwariskan oleh generasi terdahulu bukan hanya untuk dimanfaatkan bagi kepentingan generasi pewaris masa kini saja, namun juga menjadi milik generasi di masa yang akan datang. Oleh karena demikian besar manfaat situs sejarah bagi masyarakat, maka keberadaan situs sejarah tersebut wajib dijaga, dilindungi, dipelihara dalam arti dilestarikan, karena situs sejarah itu dapat menunjukkan identitas atau jati diri suatu bangsa. Makna simbolik dari situs sejarah dapat dijadikan sebagai media perekat kerukunan bangsa. Melalui situs sejarah dapat merangsang timbulnya ingatan dan kesadaran masa lalu bahwa leluhur kita adalah sama, yaitu sama-sama memiliki keunggulan kebudayaan yang pantas untuk dikagumi dan dibanggakan. Keunggulan kebudayaan yang dimiliki dapat dijadikan sebagai identitas atau jati diri bangsa. Situs sebagai fakta sejarah masa lalu merupakan buah budhi dan hasil kreativitas manusia pendukung dari kebudayaan masa lalu itu. Situs sejarah tersebut mereka bangun secara bersamasama untuk tujuan yang sama karena dilandasi oleh tujuan, cita-cita, dan kebudayaan yang sama.

Situs bersejarah warisan masa lalu yang tersebar di berbagai wilayah nusantara ini jenis, bentuk, ragam dan teknik pembuatannya tidaklah sama. Ini merupakan bukti akan keragaman etnik yang mendukung tinggalan masa lalu itu, karena masing-masing etnik memiliki kebudayaannya sendiri. Semua kebudayaan etnik itu adalah kekayaan kebudayaan bangsa. Hal ini perlu ditegaskan untuk 
memahami bahwa kebudayaan bangsa Indonesia tidak seragam (homogen). Menyadari perbedaan adalah suatu realita dalam kehidupan bermasyarakat, oleh sebab itu hendaknya keberagaman ini dijadikan mozaik yang dapat memperindah kehidupan bermasyarakat, berbangsa, dan bernegara.

Dalam mengungkap eksitensi sebuah situs sejarah, para ahli sering mengalami berbagai kesulitan dalam merekonstruksi peristiwa masa lalu. Hal ini tentu membutuhkan kompetensi, kepekaan, dan strategi sejarawan. Dalam kaitan ini tradisi yang masih eksis di tengah-tengah kehidupan bermasyarakat, seperti kebiasaan, sejarah lokal, cerita rakyat, folklor, dan mitos sering dapat membantu dalam mengungkapkan masa lalu. Bentuk bangunan atau bentuk candi, relief atau ornamen dalam situs dapat membantu sejarawan untuk merekonstruksi peristiwa masa lalu. Kearifan lokal yang dimiliki masing-masing daerah juga dapat membantu mengungkapkan masa lalu, di samping dapat dijadikan perekat sekaligus memperkokoh identitas dan jati diri bangsa (Brata, 2016).

\section{Situs Sejarah Perekat Kerukunan dan Bermakna Informatif}

Misi utama studi sejarah, bukan sematamata hanya dipandang untuk mengungkapkan fakta-fakta sebagai dasar untuk merekonstruksi cerita sejarah. Tugas utama studi sejarah sering diringkas untuk menjawab pertanyaan yang disimbolkan dengan $5 \mathrm{~W}+1 \mathrm{H}$ (what, where, when, who, why, dan how), yaitu apa yang terjadi pada situs itu, di mana situs itu dibangun, kapan situs itu dibangun, siapa yang membangun situs itu, mengapa situs itu dibangun, dan bagaimana situs itu dapat dibangun. Dua pertanyaan terakhir, yaitu pertanyaan mengapa dan bagaimana sejatinya sudah mengarah pada kajian yang lebih fokus dan mendalam terkait dengan latar belakang atau hubungan kausalitas di antara peristiwa. Namun dalam realitasnya, kajian deskriptif-naratif tidak diungkapkan secara eksplisit, hanya terangkum secara implisit pada bagian akhir dari cerita sejarah yang direkonstruksi.

Tugas sejarawan tidak semata-mata merekonstruksi masa lalu menjadi sebuah cerita sejarah, namun yang lebih penting adalah menyebarluaskan informasi tentang situs sejarah tersebut sebagai warisan masa lalu kepada masyarakat. Peranan setiap komponen bangsa ini menjadi sangat penting untuk menginformasikan keberadaan dari situs sejarah tersebut. Setiap komponen bangsa yang dimaksud di sini meliputi guru, peneliti, wartawan, pemerhati, dan kepada mereka yang peduli terhadap warisan masa lalu itu sendiri.

Bagi generasi muda atau yang dewasa ini lazim dikenal sebagai generasi milenial, sejarawan paling tidak, dapat bertindak sebagai duta dari peristiwa masa lampau. Sebagai duta, sejarawan dapat memberikan informasi berkaitan dengan situs tertentu, kondisi dan situasinya, sistem ekonomi, sosial-budaya dan politik berkenaan dengan berbagai aspek dalam kehidupannya. Melalui berbagai metode dan pendekatannya, sejarawan dapat menginformasikan secara lebih mendalam berkaitan dengan politik, ekonomi, sosial budaya dan sebagainya. Tugas sejarawan adalah mengungkapkan berbagai informasi yang dimiliki oleh situs sejarah itu melalui penelitian atau kajian terencana dan terpadu.

Hasil kajian yang dihasilkan sejarawan adalah hasil rekonstruksi dari situs sejarah tersebut yang perlu disampaikan kepada pelajar, mahasiswa, masyarakat secara 
umum, dan pemerintah baik dalam bentuk brosur, buku, film, hasil seminar, maupun pameran. Informasi seperti ini tentu sangat baik untuk memberikan edukasi kepada masyarakat luas terkait dengan eksistensi situs sejarah tersebut. Sejarawan dituntut dapat menyajikan informasi sejelas dan seoptimal mungkin tentang situs sejarah tersebut kepada masyarakat, sehingga timbul kesadaran akan arti penting dari keberadaan situs sejarah tersebut. Kesadaran tentang makna dan nilai dari situs sejarah itu diharapkan dapat menjadi faktor pendorong untuk melestarikan situs sejarah itu sebagai simbol kerukunan bagi masyarakat dan bangsa Indonesia yang plural.

Situs sejarah sebagai sumber belajar dapat diartikan sebagai sebuah tempat atau wahana yang mampu memberikan pembelajaran (edukasi) kepada siapa saja termasuk peserta didik yang datang ke situs sejarah bersangkutan. Situs sejarah merupakan tempat yang tepat dalam memberikan simulasi karena situs itu dapat secara langsung memberikan gambaran kepada pengunjung (siswa), sehingga mereka dapat secara langsung memahami apa situs sejarah itu. Dengan memanfaatkan situs sejarah, siswa dapat mengeksplor kemampuan dirinya sendiri dan dapat menggali kemampuan yang berasal dari luar untuk dipadukan sehingga mendapatkan pengetahuan yang lebih komprehensif berkaitan dengan situs sejarah tersebut.

Dalam konteks ini sejarawan dituntut lebih peka untuk lebih banyak meneliti, menggali, mengungkapkan, merekonstruksi, dan selanjutnya menginformasikan nilai-nilai kesejarahan yang terkandung dalam situs sejarah yang ada di berbagai wilayah nusantara ini. Informasi ini dapat disampaikan kepada masyarakat, pengusaha di bidang pariwisata, wisatawan, dan pemerintah. Kepada masyarakat agar masyarakat mengetahui dan memahami informasi tentang keberadaan situs tersebut, kepada pengusaha agar mereka dapat membuka peluang berusaha, kepada wisatawan sebagai informasi tentang keberadaan situs sejarah sebagai objek dan daya tarik wisata, sementara kepada pemerintah untuk mempersiapkan perijinan untuk membuka akses dan membangun berbagai akomodasi pariwisata yang dibutuhkan dan sebagainya.

\section{Situs Sejarah Perekat Kerukunan dan Bermakna Estetika}

Situs sejarah sebagai warisan masa lalu juga bermakna keindahan atau estetika. Situs sejarah memiliki keindahan dalam berbagai bentuk atau wujud, jenis, dan teknik pembuatannya sehingga menimbulkan daya tarik tersendiri. Kemegahan sebuah situs sejarah adalah lambang kejayaan masa lalu. Kemegahan dan keindahan situs tentu dapat menimbulkan rasa bangga dan kagum bagi generasi berikutnya. Bentuk, hiasan atau ornamen yang memiliki kemiripan bahkan sama yang digunakan dalam bangunanbangunan situs itu dapat kiranya dijadikan tali perekat untuk memelihara kerukunan di antara masyarakat pemiliknya. Tidak tertutup kemungkinan situs sejarah banyak menyimpan kearifan-kearifan budaya, di mana kearifan ini dapat dikembangkan untuk memperkuat kesadaran budaya bangsa dalam upaya membangun keIndonesiaan (Brata, 2017).

Namun yang harus disadari bahwa nilai estetika tinggalan masa lalu bila dibandingkan dengan nilai estetika jaman sekarang tentu sangat berbeda. Latar belakang pemikiran, kondisi politik, 
ekonomi, dan sosial budaya pada waktu situs sejarah itu dibangun mungkin berbeda dengan situasi dan kondisi pada saat ini. Seringkali yang menjadi daya tarik adalah karena kekhasan atau keunikan dari sebuah situs sejarah. Justru karena kekhasan atau keunikan yang dimiliki sebuah situs sejarah sehingga menjadi daya tarik tersendiri bagi pengunjung (wisatawan) atau masyarakat pada umumnya.

Situs sejarah yang ada di berbagai wilayah nusantara ini satu dengan yang lainnya berbeda-beda. Masing-masing memiliki kekhasan dan keunikan tersendiri. Kekhasan dan keunikan yang dimiliki sering memancarkan nilai estetika yang tinggi, sehingga menjadi daya tarik bagi siapa saja yang menyaksikan. Nilai keindahan atau estetika yang dimiliki sebuah situs sejarah dapat menggambarkan tingkat peradaban masyarakat pendukungnya. Artinya, bahwa sebuah situs sejarah bukan semata-mata hanya menunjukkan kemegahan dan kejayaan masa lalu ketika situs itu dibangun, namun juga dapat mengungkapkan tingkat kemajuan kebudayaan masyarakat pendukung dari situs tersebut.

Keindahan yang dimiliki oleh situs sejarah sering justru menjadi faktor terjadinya perusakan terhadap situs sejarah itu sendiri. Karena unik dan indah, banyak orang yang tertarik ingin memiliki bendabenda tadi, mungkin sebagai hiasan, cindera mata atau hanya sebagai kenangkenangan semata. Karena hasil tinggalan masa lalu ini banyak diminati orang, maka terjadi pencurian terhadap benda-benda itu demi mendapatkan uang tanpa berpikir tentang nilai historis dari situs sejarah tersebut. Apabila hal ini sampai terjadi dapat dipastikan nilai dan makna simbolik, informatik, dan estetika dari sebuah situs tidak mungkin dapat diinterpretasikan.
Akhirnya situs sejarah itu akan menjadi sebuah onggokan bebatuan yang tidak bernilai dan bermakna.

\section{Situs Sejarah Perekat Kerukunan dan Bermakna Ekonomi}

Salah satu konsideran UU RI No. 10 Tahun 2009 tentang Kepariwisataan menyebutkan "Bahwa keadaan alam, flora dan fauna, sebagai karunia Tuhan Yang Maha Esa, serta peninggalan purbakala, peninggalan sejarah, serta seni dan budaya yang dimiliki bangsa Indonesia merupakan sumber daya dan modal pembangunan kepariwisataan untuk peningkatan kemakmuran dan kesejahteraan rakyat sebagaimana terkandung dalam Pancasila dan Pembukaan Undang-Undang Dasar Negara Republik Indonesia Tuhan 1945". Dalam kaitan ini peninggalan sejarah dalam bentuk situs sejarah yang memiliki nilai estetika berpeluang menjadi daya tarik tersendiri bagi masyarakat dan wisatawan. Nilai estetika tinggalan masa lalu seringkali menjadi daya tarik tersendiri bagi wisatawan tanpa mengetahui konteksnya di masa lalu. Situs sejarah yang tersebar hampir di seluruh kawasan nusantara ini kemungkinan besar memiliki daya tarik tersendiri sehingga berpotensi sebagai objek daya tarik wisata.

Chris Cooper (dalam Ardika, 2007) menjelaskan bahwa atraksi wisata dapat dikelompokkan menjadi dua, yaitu atraksi wisata alam dan atraksi wisata hasil karya manusia. Kelompok atraksi wisata alam meliputi pemandangan alam (landscape), iklim, vegetasi, hutan, dan marga satwa. Sementara yang dikelompokkan ke dalam atraksi wisata hasil karya manusia adalah produk sejarah dan produk kebudayaan, termasuk juga hiburan artifisial. Berdasarkan pengelompokan seperti ini, situs sejarah sebagai hasil karya manusia 
adalah termasuk atraksi wisata hasil karya manusia.

Peninggalan sejarah dalam wujud situs sejarah yang menunjukkan kemegahan dan memiliki keidahan sehingga menjadi daya tarik bagi siapa saja yang menyaksikan termasuk wisatawan. Situs sejarah tinggalan masa lalu yang begitu indah menjadi daya tarik luar biasa, sehingga dapat dijadikan sebagai modal budaya (cultural capital) dalam pengembangan pariwisata. Artinya, wisatawan dapat mengkonsumsi situs sejarah tersebut sebagai obyek dan daya tarik pariwisata (ODTW) karena kandungan nilai dan makna simbolik, informatif, dan estetika situs sejarah tersebut.

Dimanfaatkannya situs sejarah sebagai obyek dan daya tarik wisata dapat menjadi ruang berusaha bagi masyarakat. Dapat menjadi peluang dan kesempatan kerja bagi penduduk sekitar situs itu dibangun. Namun harus diwaspadai bahwa ketika situs sejarah dijadikan sebagai obyek dan daya tarik wisata dapat diibaratkan pisau bermata dua. Pada satu sisi situs sejarah itu dapat mendatangkan manfaat ekonomi bagi kemaslahatan masyarakat, sementara pada sisi yang lain bisa terjadi pengerusakan terhadap situs sejarah tersebut. Bahkan tidak tertutup kemungkinan dengan memanfaatkan kehkasan, keunikan, dan keindahan yang dimiliki, akibatnya situs sejarah tersebut dijadikan sebagai komoditas oleh pihak-pihak yang kurang bertanggung jawab. Demikian juga karena kekhasan dan keunikan relief, ornamen atau hiasan pada situs tersebut, sehingga banyak orang yang tertarik untuk menjadikan sebagai benda koleksi, cinderamata, dan sebagainya, akibatnya situs sejarah menjadi rawan pencurian oleh oknum-oknum yang hanya mementingkan uang tanpa memahami nilai dan makna historis sebuah situs sebagai pusaka budaya.

Karena demikian besar memberikan manfaat secara ekonomi bagi masyarakat, maka menjadi peluang bagi masyarakat untuk menjalin kerjasama guna secara bersama-sama berupaya menjaga situs tersebut agar jangan terjadi perusakan atau pencurian terhadap benda-benda budaya yang ada pada situs sejarah tersebut. Karena adanya tekad, kemauan, dan semangat bersama untuk menjaga jangan sampai benda-benda yang ada pada situs sejarah itu dirusak atau dicuri dapat dijadikan sebagai perekat kebersamaan terutama bagi masyarakat yang ada di sekitar situs sejarah tersebut.

\section{PENUTUP}

\section{Kesimpulan}

Berdasarkan uraian di atas dapat ditarik simpulan sebagai berikut. Pertama, situs bersejarah adalah warisan masa lalu merupakan sebuah lokasi resmi di mana bagian sejarah, militer, budaya, atau sosial dilestarikan karena nilai warisan budaya tersebut. Situs sejarah sebagai warisan masa lalu dapat menghubungkan masa lalu dengan masa kini dan memiliki bermacam nilai dan makna yang dapat dijadikan sebagai perekat kerukunan bermasyarakat, berbangsa, dan bernegara di tengah kemasakinian yang problematis. Kedua, situs sejarah bermakna simbolik artinya situs sejarah sebagai tinggalan masa lalu merupakan ciri identitas dan jati diri bangsa, sehingga dapat dijadikan sebagai perekat kerukunan bangsa. Ketiga, situs sejarah bermakna informatif artinya situs sejarah sebagai warisan masa lalu dapat dijadikan sebagai sumber belajar sekaligus sebagai media informasi yang menghubungkan antara masa lalu dan masa kini, sehingga dapat dijadikan faktor 
perekat kerukunan masyarakat sebagai pewarisnya. Keempat, keragaman bentuk/wujud, jenis, dan teknik pembuatannya, sebuah situs sejarah dapat menimbulkan daya tarik tersendiri. Kemegahan, keunikan, dan keindahan sebuah situs dapat menimbulkan rasa bangga dan kagum bagi generasi berikutnya. Bentuk, hiasan atau ornamen yang menghiasi sebuah situs sering menunjukkan kemiripan bahkan ada yang sama, sehingga dapat kiranya dijadikan tali perekat untuk memelihara kerukunan di antara masyarakat pemiliknya. Kelima, kekhasan atau keunikan sebuah situs sejarah dapat dijadikan sebagai obyek dan daya tarik pariwisata, sehingga dapat menjadi peluang ekonomi bagi masyarakat sekitar. Demikian besar manfaat ekonomi dari sebuah situs sejarah, dapat dijadikan dasar motivasi masyarakat untuk secara bersama-sama menjaga kelestarian dari situs bersangkutan.

\section{DAFTAR PUSTAKA}

Abdullah, T. (2017). Pembelajaran Sejarah yang Reflektif dan Inspiratif. Seminar Nasional Dan Kongres Asosiasi Pendidik Dan Peneliti Sejarah (APPS).

Alvin, T. (1991). Pergeseran Kekuasaan: Pengetahuan, Kekayaan, dan Kekerasan di Penghujung Abad ke21 (H. Sulistyo (ed.)). Pantja Simpati. Ardika, I. W. (2007). Pusaka Budaya dan Pariwisata. Pustaka Larasan.

Black, James A.; Champion, D. J. (2001). Metode dan Masalah Penelitian Sosial (R. E. Koswara; Dira, Salam; Alfin (ed.)). Refika Aditama. https://lib.unikom.ac.id/opac/detail/0 -12609/METODE dan masalah penelitian sosial

Brata, I. B. (2016). Kearifan Budaya Lokal Perekat Identitas Bangsa. Jurnal Bakti Saraswati, 05(01), 9-16.
Brata, I. B. (2019). Pendidikan Karakter dan Globalisasi. Unmas Press. http://library.unmas.ac.id/index.php? $\mathrm{p}=$ fstream $\&$ fid $=135 \&$ bid $=4409$

Brata, I. B. (2017). Menyama Braya: Representasi Kesadaran Kolektif Lokal Memperkuat Identitas Nasional. Seminar Nasional Dan Kongres Asosiasi Pendidik Dan Peneliti Sejarah (APPS) SeIndonesia, 1-13. http://repository.unmas.ac.id/medias/ journal/EJR-0050.pdf

Hasan, A. (2017). Pendidikan Sejarah untuk Kehidupan Berbangsa dan Masa Depan Bangsa. Seminar Nasional Dan Kongres Asosiasi Pendidik Dan Peneliti Sejarah (APPS).

Miles, M. B., Huberman, A. M., \& Saldaña, J. (2014). Qualitative Data Analysis (3rd ed.). Sage Publications.

Wija, I. G. (2002). Pokok-Pokok Pikiran Mengenai Strategi Pengembangan Kurikulum Baru Pendidikan IPS di LPTK. Seminar Nasional Fakultas Pendidikan IPS IKIP Negeri Singaraja.

Yusuf, D. (2011). Permasalahan Pembelajaran Sejarah di Indonesia. https://www.slideshare.net/sejarahak ademika/permasalahanpembelajaran-sejarah-di-indonesia 